\title{
Mistakes in Solving Geometry Problems
}

\author{
Akhsanul In'am \\ University of Muhammadiyah Malang \\ ahsanul_in@yahoo.com
}

\begin{abstract}
The objective of this present research is to study the mistakes in solving geometry problems viewed from the Polya Approach in terms of the understanding and implementation aspects. The subject was the second semester students of Mathematics Education Program, University of Muhammadiyah Malang at the even academic year of 2017-2018. A qualitative approach with the descriptive type involving some students with focus on their results in learning geometry was adopted. An analysis was made by paying attention to the results of the answers of the final test and by making observations during the learning process. The research results showed that mistakes the students made were caused by their improper understanding of the basic implementation adopted in solving problems namely theorems, postulates, and definitions. The mistakes in understanding gave impacts on the implementation in solving problems which are not appropriate with the correct answers to the problems.
\end{abstract}

Keywords: geometry, understanding, problems, implementation

\section{INTRODUCTION}

There are some research results dealing with the abilities in solving mathematical problems. This shows that mathematical problem solving is an interesting and contextual study in the study of mathematical learning. Viewed from the abilities in the results of mathematical learning, it can be stated that the learning achievement in mathematics is better, but it serves as the indicators of abilities in problem solving [8]. A review aspect is one of the problems in problem solving [15]. Another research, moreover showed that the review aspect is problematic for those with either high, moderate or low abilities [6].

Learning mathematics is conducted in a staged and sustainable way, so that any ability in solving mathematical problems is not acquired through memorization [5]. As a result, the learning process in the classroom through interactions with other students and guidance from the lecturers is really important $[5,13$, 15]. Learning mathematics is the effort to improve the abilities in the ways of thinking and in logics in problem solving, especially in learning geometry which is the way to bring students towards critical and logical thinking [7. $3,4,9,12]$. It can also be stated that through mathematics learning, students may be brought towards solving problems well [2] and it can be implemented in daily life.

It can also be said that effectiveness in mathematics learning can be seen from abilities in solving mathematical problems [11]. Therefore, abilities in problem solving are very important aspects to be mastered by students and they can also be used as the basis in developing other fields of sciences [1, 10, 14, 16]. Moreover, they may also become motivation to the students to find new knowledge $[1,7]$.

There are two factors that cause the students to be difficult in problems solving namely the students and the lecturer. Viewed from the factor of the students, it can be said that usually students have less understanding of what is learned and it often happens that the memorization factor that is the basis, instead of the reasoning that should be developed. From the lecturer, it should note that she or he, during the learning activities, should not have some prejudice that students have got abilities in learning mathematics, but dialogues should be developed so that the materials to be taught may really be understood by the students [9].

Geometry is one of the materials taught with the aim to enable the students to have logical and critical thinking and may use the materials as the basis in doing their daily life and also in developing other sciences. When solving geometry problems, students are guided on how to give answers with proper steps and logical bases [7]. However, on the basis of the research results given by some experts, it is shown that in solving geometry problems, students in trying to find the answers to the problems, were found not to be based on the proper rules and not to show their abilities in logical thinking. Therefore, in this present research, how students understand and solve geometry problems would be examined.

\section{METHOD}

A qualitative approach with descriptive type was employed. The subject was students taking the geometry course in the even semester in the academic year of 2017/2018. Data were obtained through observations and documents of the results of the answers to the final examination in the geometry course. Subject was determined by paying attention to the results of the answers to the problems containing the understanding and the implementation in solving geometry problems. The data were analysed by examining the documents of the results of the final examination in the even semester in the academic year of 2017/2018 and the observations during the lecturing activities.

\section{RESULTS}

On the basis of the documents of the results of the semester final examination that had been examined, some answers with characteristics of mistakes in the 
problem solving at the understanding and implementing aspects on the basis of the Polya approach were chosen.

One of the answers made by a student for the problem number 2, as shown in Picture 1, showed that the student did not understand the proper steps in solving a problem. It can be seen from some improper steps. The first and the second steps were correct, since they were known, meanwhile the third step written in the statement $\mathrm{AB} \cong \mathrm{AD}$ with the reason of congruence equation showed two mistakes. First, the congruence involving $\mathrm{AB}$ and $\mathrm{CD}$ was mistakenly written, since the symbol is for the line segment that should be written in the following manner, namely $\overline{\mathrm{AB}} \cong \overline{\mathrm{AC}}$. The next mistake is the reason that is not based on the correct knowledge. The reason presented should be the definition of a parallelogram that the sides facing each other of a parallelogram is congruent.

The statement in the step 4 was also wrong. It is seen from the fact that the respondent did not understand the opposite angles where they should be based on definitions, theorems or postulates when he or she made a statement. As a result, a wrong statement occurred and this clearly gave an impact on the reason presented: an opposite equation. It should be noted that an opposite angle is two angles which are formed by two lines intersecting at a point.

The fifth step was much worse, since the statement presented was a triangle that intersects another triangle due to the secant equation. It is a fact that a wrong understanding would result in a great impact. Although the respondent did the problem, but its direction was not clear. The statement of the sixth step showed that the $\triangle \mathrm{ABF}$ was opposite to the $\triangle \mathrm{EDC}$. Such an opposite statement is for an angle, but the respondent stated that there were three triangles which were opposite due to the opposite equation. This was also the case in the seventh step.

While the eight steps were written as the one that should be proven. This showed that the respondent really did not understand what to do to solve this problem. It could be seen although it seemed that the solution of the problem was coherent, but the third to the seventh statements were made without any understanding that may give an impact on the wrong proof.

From the result of the respondent's work for problem no. 2, it is shown that the first to the third statements were merely rewritten from what is known, instead of why a statement exists and of the impact of the statement on the next statements. The statement should be that from the first step stating the isosceles triangle $\triangle \mathrm{ABC}$ could give an impact on the statement that $\angle \mathrm{B} \cong \angle \mathrm{C}$ because of the two sides of a congruent triangle due to the isosceles triangle $\mathrm{ABC}$.

The statement $\overline{\mathrm{AD}} \cong \overline{\mathrm{AE}}$, with the reason that congruence is a statement with a good basis. This proves that the respondent really did not understand the steps that should be taken to prove the $\triangle \mathrm{ADE}$, whereas the step should be the last step as a basis for proving the isosceles triangle $\triangle \mathrm{ADE}$ and some steps were needed to make the statement. This was also the case for the fifth step stating the $\overline{\mathrm{DB}} \cong \overline{\mathrm{EC}}$, a statement that really showed that the respondents did not understand the steps taken to prove the existence of a isosceles triangle.

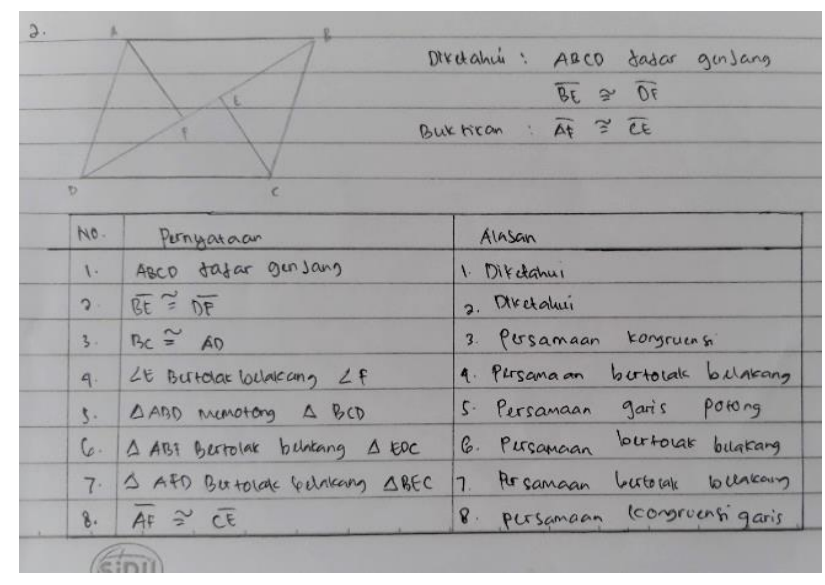

Figure 1: Result of Work for Problem

The sixth statement that $\angle \mathrm{B} \cong \angle 1$, is an instinctive statement made by the respondent. Although the statement was correct, but the reason did not have any basis, so the sixth step is incorrect. Moreover this situation was worsen due to the reason shown in the step no. 3, namely it is known..... this is really fatalistic

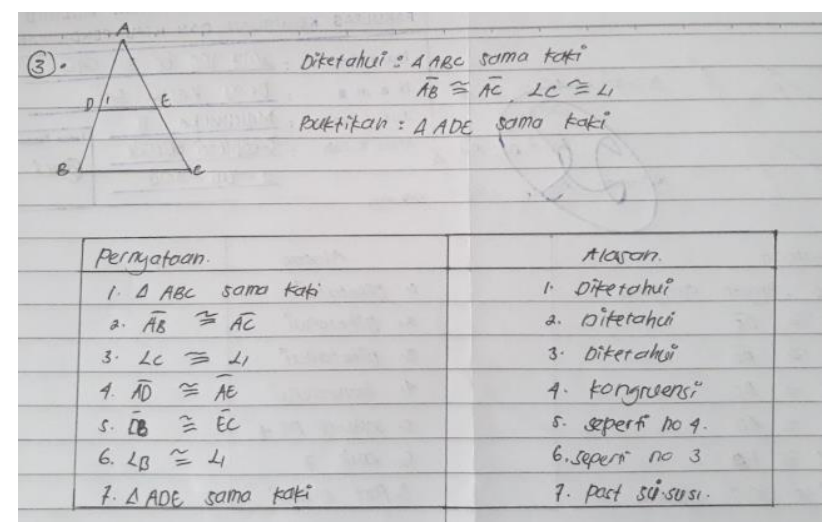

Figure 2: Result of Work for Problem

\section{DISCUSSION}

The research results show that the respondent did not understand the steps to take in solving problems. This is different from previous researches showing that students with the low and moderate categories had difficulties in the review because of the limited time, while the students with the high category did not review their works because they were sure that their works had been correct already $[6,15]$.

But this present research also reinforces a research [11] that the ability in solving problems serves as a 
benchmark of the understanding of mathematics materials.

\section{CONCLUSION}

The ability in solving mathematical problems may be taken as one of the benchmarks to know the achievement in mathematics. This present research has studied the results of the answers given by students with low level ability. From the descriptions it can be seen that there are two aspects of the Polya approach namely the understanding of the steps in solving problems that are possessed by the respondents. This may give impacts on the implementation of problem solving.

\section{REFERENCES}

[1] Anisa, W. N., Peningkatan Kemampuan Pemecahan Masalah dan Komunikasi Matematik Melalui Pembelajaran Pendidikan Matematika Realistik Untuk Siswa SMP Negeri Di Kabupaten Garut. Jurnal Pendidikan Dan Keguruan, 1(1)., 2014

[2] Delyana, Peningkatan Kemampuan Pemecahan Masalah Matematika Siswa Kelas VII Melalui Penerapan Pendekatan Open Ended. LEMMA, II(1), 26-34., 2015.

[3] Effendi, L. A, Pembelajaran Matematika dengan Metode Penemuan Terbimbing Untuk Meningkatkan Kemampuan Representasi Dan Pemecahan Masalah Matematis Siswa Smp. Jurnal Penelitian Pendidikan, 1(2), 1-10, 2012

[4] Husnidar, Ikhsan, M., \& Rizal, S,Penerapan Model Pembelajaran Berbasis Masalah untuk Meningkatkan Kemampuan Berpikir Kritis dan Disposisi Matematis Siswa. Jurnal Didaktik Matematika, 1(1), 71-82. 2014

[5] Ifanali, Penerapan Langkah-Langkah Polya Untuk Meningkatkan Kemampuan Pemecahan Masalah Soal Cerita Pecahan pada Siswa Kelas VII SMP Negeri 13 Palu. Jurnal Elektronik Pendidikan Matematika Tadulako, 1(2), 148-158., 2014.

[6] In'am, A, The Implementation of Polya Method in Solving Euclidean Geometry Problem, IES Vol. 7 No. 72014

[7] In'am, A, Geometri, Malang: Bayu Media,, 2002
[8] Joseph, K. Y. K, An Exploratory Study of Primary Two Pupils ' Approach to Solve Word Problems. Journal of Mathematics Education, 4(1). 2011.

[9] Khasanah, N. U,Peningkatan Kemampuan Pemecahan Masalah Matematika Melalui Strategi Realistic Mathematics Education Berbasis Group Investigation Universitas Muhammadiyah Surakarta. Universitas Muhammadiyah Surakarta, 2016.

[10] Marfuqotul, H., \& Sutama.). Penerapan Problem Based Learning untuk Peningkatan Kemampuan Pemecahan Masalah Matematika Pada Siswa Kelas VIII Semester II SMPN 1 Teras Tahun 2014/2015. Universitas Muhammadiyah Surakarta, 2015

[11] Pimta, S., Tayruakham, S., \& Nuangchalerm, P, Factors Influencing Mathematic Problem-Solving Ability of Sixth Grade Students. Journal of Social Sciences, 5(4), 381-385, 2009

[12] Purnamasari, P. D, Analisis Kemampuan Pemecahan Masalah Matematika Siswa Kelas XI SMK Muhammadiyah 1 Patuk Pada Pokok Bahasan Peluan. Jurnal Pendidikan Matemtika Dan Sains, 1-7., 2015

[13] Sarbiyono, Penerapan Pendekatan Matematika Realistik Terhadap Kemampuan Pemecahan Masalah Matematis Siswa. Jurnal Reviem Pembelajaran Matematika, 1(2), 163-173, 2016

[14] Sulistiyorini, \& Setyaningsih, N, Analisis Kesulitan Siswa dalam Pemecahan Masalah Soal Cerita Matematika pada Siswa SMP. Prosiding Seminar Pendidikan Matematika 2016, 1-9, 2016.

[15] Ulya, H. Profil Kemampuan Pemecahan Masalah Siswwa Bermotivasi Belajar Tinggi Berdasarkan IDEAL Problem Solving. Jurnal Konseling GUSJIGANG, 2(1), 90-96, 2016.

[16] Untarti, R, Efektifitas Problem Based Learning (PBL) Terhadap Kemampuan Pemecahan Masalah Mahasiswa Pada Mata Kuliah Statistika Inferensia. Journal Mathematics Education, 1(1), 76-86, 2015. 